IZA DP No. 4516

Savings for Unemployment in Good or Bad Times: Options for Developing Countries

David Robalino

Milan Vodopivec

András Bodor

October 2009 


\title{
Savings for Unemployment in Good or Bad Times: Options for Developing Countries
}

\author{
David Robalino \\ World Bank \\ Milan Vodopivec \\ World Bank \\ and IZA
}

\author{
András Bodor \\ World Bank
}

\section{Discussion Paper No. 4516 \\ October 2009}

\author{
IZA \\ P.O. Box 7240 \\ 53072 Bonn \\ Germany \\ Phone: +49-228-3894-0 \\ Fax: +49-228-3894-180 \\ E-mail: iza@iza.org
}

\begin{abstract}
Any opinions expressed here are those of the author(s) and not those of IZA. Research published in this series may include views on policy, but the institute itself takes no institutional policy positions.

The Institute for the Study of Labor (IZA) in Bonn is a local and virtual international research center and a place of communication between science, politics and business. IZA is an independent nonprofit organization supported by Deutsche Post Foundation. The center is associated with the University of Bonn and offers a stimulating research environment through its international network, workshops and conferences, data service, project support, research visits and doctoral program. IZA engages in (i) original and internationally competitive research in all fields of labor economics, (ii) development of policy concepts, and (iii) dissemination of research results and concepts to the interested public.
\end{abstract}

IZA Discussion Papers often represent preliminary work and are circulated to encourage discussion. Citation of such a paper should account for its provisional character. A revised version may be available directly from the author. 
IZA Discussion Paper No. 4516

October 2009

\section{ABSTRACT \\ Savings for Unemployment in Good or Bad Times: Options for Developing Countries}

The paper describes and evaluates unemployment insurance savings accounts (UISAs) - a relatively new and not well-known way of providing unemployment benefits. The UISAs reduce work disincentives by allowing recipients to keep their own unused unemployment contributions, and offer the possibility to extend coverage to informal sector workers. In addition, if integrated with mandatory pension systems (and even social pensions), UISAs can be rapidly deployed and at a low cost, thus becoming a realistic tool to protect workers from the effects of the financial crisis. Even during normal times, the integration with the pension system - and social security in general - would give more flexibility to individuals in the management of short and long term savings (i.e., pension wealth) while avoiding unnecessary administrative costs. The paper discusses issues related to incentives, redistribution, and viability, and outlines a policy framework for design and implementation. It argues that the UISAs system is especially attractive for developing countries, where the "self-policing" nature of the system is particularly important given a much larger informal sector and weaker administrative capacity in comparison to developed countries.

JEL Classification: J65, J68

Keywords: unemployment insurance, unemployment insurance savings accounts, unemployment

Corresponding author:

Milan Vodopivec

The World Bank

1818 H Street, NW

Washington, D.C. 20433

USA

E-mail: Mvodopivec@worldbank.org 


\section{Table of Contents}

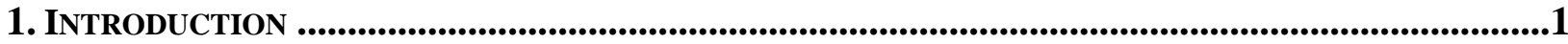

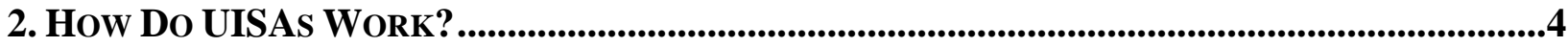

3. INCENTIVES, REDISTRIBUTION, AND VIABILITY ......................................................................66

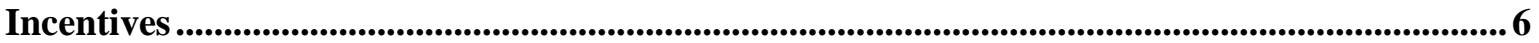

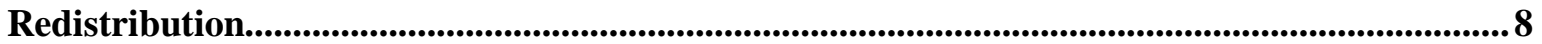

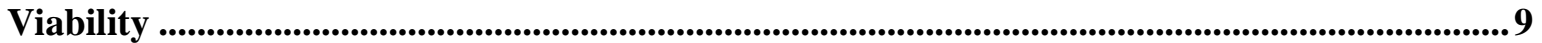

4. DESIGNING UISAS IN DEVELOPING COUNTRIES............................................................10

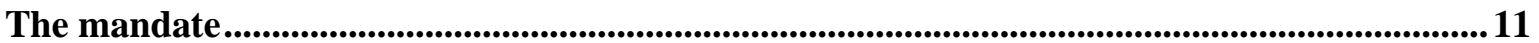

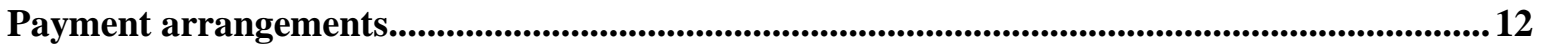

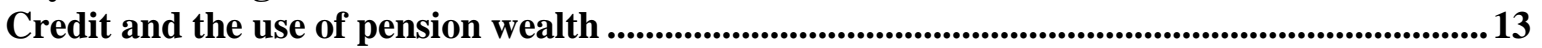

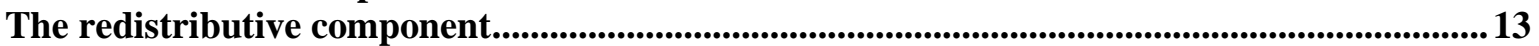

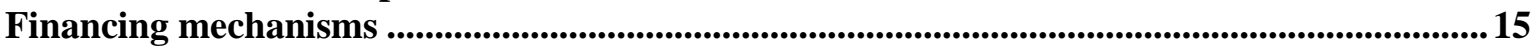

5. How UISA-CuM-BORROWING SYSTEMS CAN SERVE AS A RAPID RESPONSE TO

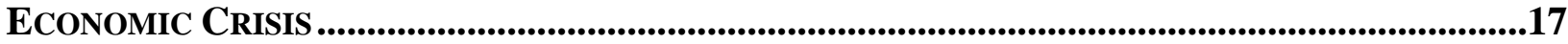

6. IMPLEMENTING AND MANAGING UISAS ........................................................................18

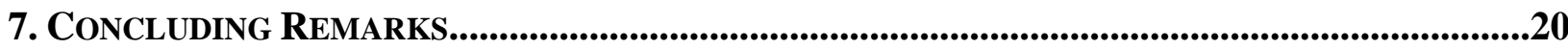

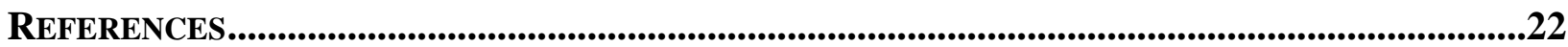

ANNEX 1: STYLIZED FEATURES OF UISAS FROM SELECTED LATIN AMERICAN COUNTRIES ...25

ANNEX 2: THE CHILEAN UISAS-CUM-SOLIDARITY FUND SCHEME.......................................26

ANNEX 3: Formalizing THE WELFARE EFFECTS OF RESTRICTIONS IN THE ACCESS TO

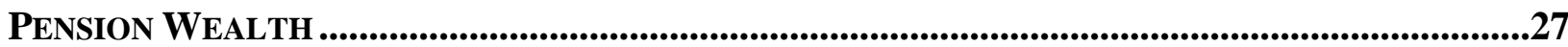

The three period model of optimal savings for pensions and unemployment ............................ 27

Simulating career paths and the welfare impact of restrictions on the use of pension wealth 33

Table of Figures

Figure 1: Survival in Unemployment of UI Recipients, Slovenia, Before (Solid Line) and After (Dotted Line) the Legislative Change of Potential Benefit Duration............................................2

Figure 2: The Chilean USIA System ..............................................................................26

Figure 3: Characterizing Optimal Consumption under Uncertainty in Employment in Period 2

Figure 4: Conditions under which Restrictions on the Use of Pension Wealth are Welfare

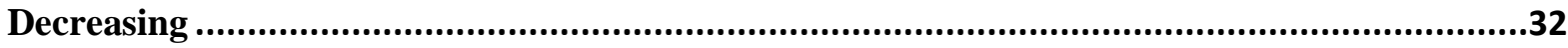

Figure 5: Optimal Consumption, Optimal Savings and Restrictions on Pension Wealth..........33

Figure 6: Welfare Impact of Alternative Restrictions on the Use of Pension Wealth................36 


\section{Savings for Unemployment in Good or Bad Times: Options for Developing Countries \\ David Robalino, Milan Vodopivec, and András Bodor*}

\section{Introduction}

Many developing countries are considering the introduction of unemployment benefit schemes. Traditionally, the incidence of unemployment benefit (UB) programs has been strongly related to the level of development of a country (Vodopivec, 2004 and 2006). Increasingly, however, even lower middle-income countries such as Jordan, the Philippines, and Sri Lanka are contemplating the introduction of some form of UB system. The reasons are twofold. First, countries are being more exposed to foreign markets and are thus becoming more vulnerable to global financial and economic crises. And the current financial crisis has shown that the majority of low and middle income countries does not have in place a system to provide adequate income protection to most workers in the case of job loss. Second, in developing countries, the balance between job and worker protection is tilted in the favor of the former. The introduction of a UB program is viewed as paving the way to reform overly restrictive employment protection legislation. In essence, removing excessively restrictive severance pay (and dismissal) regulation would not only boost the creation of more and better jobs, but also improve job prospects for vulnerable groups (Kugler, 2004 and 2005). Because reducing job protection is an extremely sensitive task, such reforms can often only be implemented if accompanied with a more robust income protection system for workers - and the introduction of an UB program is arguably the best option.

Unfortunately, introducing UB to developing countries is not an easy task. ${ }^{1}$ Experience from developed and transition countries shows that while conventional (risk-

\footnotetext{
* The authors, David Robalino, drobalino@worldbank.org; , Milan Vodopivec, Mvodopivec@worldbank.org, and András Bodor, abodor@worldbank.org. The findings, interpretations, and conclusions expressed in this paper are entirely those of the authors. They do not necessarily represent the view of the World Bank, its Executive Directors, or the countries they represent.

${ }^{1}$ Today, the most prevalent system used in developed and transition countries is unemployment insurance (UI). Employees and employers contribute to a common pool: when contributing workers become unemployed, conditional on a certain vesting period, they can withdraw earnings-related benefits for a given period of time.
} 
pooling type) unemployment insurance (UI) provides good protection to formal sector workers and can help reduce poverty, it suffers from two major weakness: (i) leaves out informal sector workers, and (ii) creates moral hazard that increases work disincentives and thus imposes important efficiency costs. ${ }^{2}$ In Slovenia, for example, the shortening of the potential duration of UI benefits reduced substantially the length of the unemployment spell of recipients (see Figure 1).

\section{Figure 1: Survival in Unemployment of UI Recipients, Slovenia, Before (Solid Line) and After (Dotted Line) the Legislative Change of Potential Benefit Duration}

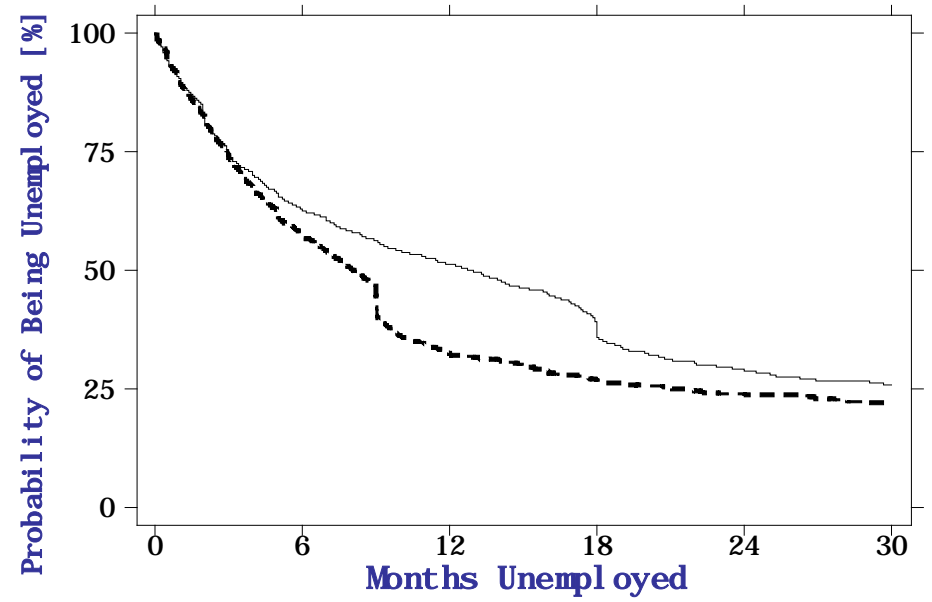

Source: van Ours and Vodopivec [2008].

Note: The study uses a 'natural experiment' - the October 1998 change of the Slovenian UI law - that reduced the potential benefit duration for the group shown above from 18 to 9 months. (The shortening of the potential benefit duration had no detectable effect on wages, the probability of securing a permanent rather than a temporary job, or the duration of the post-unemployment job - see van Ours and Vodopivec, 2008.)

A standard, OECD-type UI system is therefore not a good fit for developing countries: not only do these countries have vast informal sectors whose workers would be left out of the UI system, they also have much weaker administrative capacity than developed countries. Because checking benefit eligibility imposes large informational and institutional demands, particularly under abundant and diverse employment opportunities in the

\footnotetext{
${ }^{2}$ For a summary of UI performance in developed and transition countries, see Holmlund [1998] and Vodopivec et al. [2005], respectively.
} 
unobservable informal sector, the resulting weak monitoring would make the incentive problem of the standard UI system much worse (Vodopivec, 2009).

This paper argues that to provide adequate income protection to a majority of workers without damaging work incentives developing countries should consider the socalled unemployment insurance savings accounts (UISAs) design. These accounts reduce work disincentives by allowing recipients to keep their own unused unemployment contributions and offer the possibility to extend coverage to informal sector workers. In addition, if integrated with mandatory pension systems (and even social pensions), UISAs could be deployed rapidly and at a low cost, thus becoming a realistic tool to protect workers from the effects of the financial crisis. Even during normal times, the integration with the pension system - and social security in general - would give more flexibility to individuals in the management of short and long term savings (i.e., pension wealth), while avoiding unnecessary administrative costs.

The paper is organized in seven sections. The next section describes in more detail how UISAs work. Sections 3 and 4 then deal respectively with issues related to incentives, redistribution, and institutional viability; and key policy choices that countries need to make in terms of the mandate of the system, payment and credit arrangements, the design of a redistributive component, and the related financing mechanism (including the pension wealth when available). Sections 5 and 6 discuss in turn how UISAs could be rapidly implemented across countries to provide income protection to unemployed workers in times of crisis; and what the key institutional arrangements would be. The main messages from the paper are summarized in Section 7. A Technical Annex is also included, which uses a three period consumption/savings model and simulations of labor market transitions between employment and unemployment to show how reducing restrictions in the use of the pension wealth to finance unemployment benefits can increase welfare. 


\section{How Do UISAs Work?}

Unemployment insurance savings accounts (UISAs) are a relatively new program, although Brazil has used them since the 1960s. More recently, several other Latin American countries (Argentina, Chile, Colombia, Ecuador, Panama, Peru, Uruguay, and Venezuela) have introduced UISAs (see Robalino and Sanchez-Puerta, 2009).

The general operation of UISAs is straightforward and transparent. Employers deposit some specified fraction of each worker's earnings in a special individual savings account on a regular basis (see Annex 1 for a description of the stylized features of UISAs in selected Latin American countries). In Chile workers are also required to make regular contributions to their accounts. Upon separation - and in most countries, regardless of the reason for separation - workers can make withdrawals from their savings accounts as they deem fit (some programs allow access before separation for health, education, and housing). In Brazil workers can access their accounts only in the case of involuntary separation, and employers are required to make an additional payment of 40 percent of the account balance to the individual. In all countries, positive account balances are added to old-age pensions at retirement.

Several types of UISA programs can be distinguished:

- Pure UISA program, in which withdrawals are strictly limited by the balance of the UISA that is, the balance on an individual's UISA must always be nonnegative. This program is identical to a prefunded severance pay program.

- UISA-cum-borrowing, in which within predetermined limits, individuals can borrow money beyond their UISA balances.

- UISA-cum-solidarity fund, in which upon depletion of their own accounts, individuals may receive payments from the solidarity fund (see Annex 2 for a description of the Chilean system introduced in 2002).

The last two programs combine self-insurance with public insurance. The selfinsurance mechanism via mandatory savings is complemented by other mechanisms to 
improve the adequacy of protection. The second program (UISA-cum-borrowing) does so by allowing workers, at least temporarily, to run into the red in their UISAs. Under certain circumstances (e.g., upon retirement) the repayment of such borrowing can be subsidized, i.e. this mechanism also allows for redistribution across plan members. In the case of the third program (USIA-cum-solidarity fund), self-insurance is augmented with an explicit redistributive component.

To improve both welfare and efficiency, UISAs can be combined with pension programs to provide protection against both unemployment and old age. Benefits are financed via a combination of withdrawals from an individual savings account (on which a worker accumulates his/her contributions for unemployment as well as for old-age pensions) and, under certain circumstances, also from a public UI (which operates on a pay-as-you-go basis). Stiglitz and Yun [2005] show that such a system can offer not only a superior provision of insurance and thus consumption smoothing but also significantly reduce disincentives as compared to the traditional UI system. Stiglitz and Yun [2008] also argue that in the case of countries committed to the universal provision of a minimum old-age pension guarantee, an unemployment insurance mechanism with borrowing against the pension wealth could be extended to provide coverage to informal sector workers as well. We develop these ideas later to prepare a response to the financial crisis (see also Annex 3).

It is also possible, in principle, to combine other risks under one integrated program. This allows pooling of the self-insurance component and reducing the amount of savings necessary for providing the same insurance under separate programs. Thus, there are proposals to include other social risks such as disability and health under the same roof. Under certain conditions these integrated systems are welfare improving (Orszag et al., 1999). Ultimately, the integration of risk management across the various social insurance components and the pooling of financial resources can offer better consumption smoothing, thus welfare improvement, outcomes over the life-cycle. 


\section{Incentives, Redistribution, and Viability}

UISAs can provide important benefits by improving work incentives and allowing informal sector workers to join the UB system. Yet, potential drawbacks exist too. Because it does not allow for redistribution - at least in the case of the pure UISA - the system may offer too little protection to individuals with low savings capacity. In addition, there are concerns about the institutional demands to manage and administer the system and the level of development of the financial sector required to invest efficiently the savings of workers. This section discusses the extent of these benefits and potential costs.

\section{Incentives}

The main rationale and key advantage of a UISA program over traditional UI is its potential for improving the incentives of job seekers and employed workers. As several theoretical articles show, UISAs can radically change workers' incentives. Indeed, the system increases both the on-the-job effort of employed workers and the job search effort of unemployed workers (Orszag and Snower, 2002; Orszag et al., 1999). Thus, by internalizing the costs of unemployment benefits, UISAs avoid (or at least severely limit) the moral hazard inherent in traditional unemployment insurance. As a result, they have the potential to substantially decrease overall unemployment. In addition, the absence of redistribution within the core system lowers the tax component of the social security contribution, which can raise employment levels (Robalino and Sanchez-Puerta, 2009). Finally, simulations based on a behavioral model show that UISAs can increase contribution densities relative to UI both among high and low income workers (Robalino et al., 2009).

Another way of looking at the improved incentives is noting that the UISA system is based on lifetime income, not current income, which is much more volatile. By doing so, it enables workers to self-finance shorter unemployment spells and reserves public funds to be targeted to those facing larger shocks. The system thus eliminates the "piggy-bank" function of unemployment insurance (redistribution across the life cycle). This redistribution represents the majority of spending in welfare states (Barr [2001] reports that two-thirds to 
three-quarters of welfare-state spending is life-cycle redistribution). Eliminating this function reduces taxes and disincentives.

While empirical evidence on the incentive effects of UISAs was lacking, a recent study of the Chilean unemployment benefit system corroborates theoretical predictions that UISAs improve work incentives. $\quad$ Using a mixed proportional hazard rate model, van Ours et al. [2009] examine the determinants of the job-finding rate of unemployment benefit recipients under the Chilean program and find that: (i) the larger the resources on the UISA at the start of the unemployment spell (and thus the lower the potential benefits from the solidarity fund), the higher the probability of exit from unemployment of benefit recipients; (ii) for a benefit recipient not using the solidarity fund, the amount of accumulation on the UISA does not affect the hazard rate from unemployment, suggesting that such individuals internalize the costs of unemployment benefits; (iii) for beneficiaries using the solidarity fund, the unemployment duration dependence pattern is consistent with moral hazard effects; and (iv) finally, for beneficiaries relying on UISAs only, the pattern is free of such effects.

Notable other labor market and productivity effects resulting from a severance pay reform have also been confirmed. Kugler [2004 and 2005] examines the effects of the 1990 conversion of Colombia's severance pay program into a funded severance pay with individual accounts and shows that the reform improved labor mobility by increasing both hiring and dismissals. ${ }^{3}$. Moreover, Eslava et al. [2009] show that increased labor and capital turnover after the labor and capital market reforms in the early 1990s increased productivity, with the labor effect being particularly important.

Clearly, high mandates for precautionary savings and/or low rates of return on savings can induce incentive problems of their own. UISAs in this case can produce excessive turnover and informal work by encouraging workers to choose to become unemployed (or informal workers) in order to "get their money back." This problem has been reported and analyzed in the case of the Brazilian Fundo de Garantia do Tempo de Servico (FGTS), where rates of return on savings are below market rates and UISAs co-exist

\footnotetext{
${ }^{3}$ Because of the way the new system was phased-in, employers reduced real wages to finance the cost of the transition (75-87 percent of the cost of transfers were financed in this way)
} 
with unemployment insurance (see Robalino et al., 2009; Robalino and Sanchez-Puerta, 2009). A similar problem persists in Chile in the case of employees with fixed-term contracts (SAFP, 2007). In general, the problem of a mandate for pre-cautionary savings that is too large is aggravated when individuals have difficulties accessing credit and thus cannot disave.

UISA-cum-borrowing programs may also create incentives to "dive and run." That is, workers may borrow and then withdraw from the formal sector and take a job in the informal sector, thereby avoiding repayment of the debt upon reemployment. Nonetheless, as discussed above, one could use pension wealth as "collateral” within an integrated UISApensions program.

\section{Redistribution}

By design, pure UISAs neither pool risks nor redistribute income. Young workers may thus not be able to accumulate enough savings at the time of separation to be able to self-finance their unemployment spells. Moreover, relying on self-insurance implies higher contribution rates than under UI and these might simply not be affordable to low income workers. The potentially inadequate protection to this class of workers is the program's most serious shortcoming.

At the same time, the type of implicit redistribution that exists within classical UI systems is not always progressive and can be costly. Indeed, redistribution in the UI system depends, in part, on take-up rates. Because high income workers tend to have higher contribution densities, they are also more likely to meet eligibility conditions (for a discussion of the case of Brazil, see Robalino et al., 2009). This implicit and non-targeted redistribution also increases the tax component of the social security contribution, which can have negative effects on employment (and promote informal work).

UISA-cum-borrowing and UISAs-cum-solidarity fund, on the other hand, can incorporate an explicit redistributive arrangement. This can be done through ex-ante and ex-post arrangements. Ex-post arrangements involve forgiving negative account balances upon retirement in the UISA-cum-borrowing option and allowing workers to withdraw 
benefits from a solidarity fund once their unemployment savings have been depleted (such as in Chile). Ex-ante arrangements imply matching the contributions that employers and employees make to the UISA system. In both cases, the subsidies/transfers can be targeted to low income workers with limited savings capacity. This can reduce the cost of redistribution and therefore the tax burden and associated distortions.

Some simulation analyses suggest that redistribution under UISA is smaller than under UI. The argument is that under UISAs a larger share of benefits is self-financed (see Feldstein and Altman [1998] for the United States and Vodopivec [2008] for Slovenia). Moreover, the distributional effects of substituting UI with UISA go in the "wrong" direction that is, they tend to hurt the poor. Assuming unchanged benefits and behaviors, Feldstein and Altman find that individuals in all quintiles except the bottom one slightly gain from this substitution, and individuals in the bottom quintile slightly lose.

This does not have to be the case if the redistributive component of the UISA is well designed. On the contrary, redistribution targeted towards the lowest quintiles - would actually help low income workers, turning them into the "winners" of the introduction of such a program. Moreover, as mentioned above, UISAs open the door to the coverage of low income workers in the informal sector, the very individuals who are usually excluded from any form of redistribution. This is because when redistribution is explicit and well targeted, its negative effects on incentives can be better controlled. First, fewer workers would be affected (i.e., those below the "eligibility line"). Second, those affected would be lower productivity workers with lower reservations wages and shorter unemployment spells. Thus, UISAs could be extended to informal workers without large effects on employment levels and unemployment rates.

\section{Viability}

Judged by two important measuring rods - administrative requirements and the ability of individuals to self-insure - UISAs provide a viable alternative. First, the administrative demands of UISAs are not great, not much different from those necessary to manage a contributory pension system (no matter whether funded or pay-as-you-go). The main 
difference is in terms of administrative controls to check whether beneficiaries are keeping their eligibility for benefits - but as discussed below, these controls would need to be less stringent under UISAs.

Second, simulation studies show that the proportion of workers that can self-insure is also reasonably large. The usual concern is that UISAs rely primarily on a life-cycle pooling of resources, with the intention to reduce the risks involved in cross-sectional pooling. For individuals with limited savings capacity and short contribution densities, a savings-based system would not be a viable alternative to the traditional UI system without large transfers from the government or a payroll tax. Simulations for the United States show that in high income countries this would not be an issue (Feldstein and Altman, 1998). Indeed, over a 25 year period only a small proportion of workers (5-7 percent) end their working life with negative balances. Ultimately, the cost to taxpayers is reduced by more than 60 percent. In middle income countries the prevalence of negative balances may be higher, but the level of transfers or the tax needed to finance the "debt" does not need to be higher than under UI. In the case of Slovenia, for instance, [2008b] shows that under a modest regime, only onequarter of workers end their working life with negative cumulative balance, and 43 percent ever experience a negative UISA balance. For more generous systems the respective numbers are much larger. Nonetheless, for the same level of benefits, the explicit redistribution under UISA costs only 41 percent of the taxes under UI. Indeed, under UISA individuals would have better incentives to contribute and as discussed above, redistribution can be better targeted.

\section{Designing UISAs in Developing Countries}

The previous section argued that, overall, UISAs can be a viable and efficient/equitable system to provide unemployment benefits. However, the success of the system will ultimately depend on its design. This section provides some guidelines regarding key policy choices that countries need to make. They are related to: (i) the mandate of the scheme: what benefits, for whom, and how; (ii) payment systems and credit arrangements; (iii) vesting periods, targeting systems, and type of transfers in the redistributive component; and (iv) financing mechanisms. 


\section{The mandate}

In terms of benefits, there are four key parameters that define what individuals at different levels of income receive from the system. These are: the replacement rate (insurance function), the minimum benefit (adequacy function), the ceiling on covered earnings (which implies a maximum contribution and a maximum benefit), and the duration of the minimum benefit. The minimum benefit increases the replacement rate for low income workers. The ceiling on covered earnings, on the other hand, reduces the replacement rate of middle and high income workers. The rationale is that the latter have more capacity to diversify savings and make insurance arrangements outside of the mandatory system. Moreover, forcing high income workers to contribute on their full earnings would impose levels of precautionary savings that are too high (an implicit tax) and that can induce evasion or increase turnover (see above).

While no universal standard exists to choose these parameters, it is desirable to start with modest objectives and to avoid discretion. To the extent possible, choices should be based on an understanding of the nature of unemployment shocks and their impact on earnings. In addition, it is important (i) to start with a conservative mandate that can then be gradually expanded if considered necessary (this is important both for the contributory and non-contributory parts of the benefits given uncertainties regarding the potential effects of the program on behaviors); and (ii) to link the minimum benefit and the ceiling to real variables that measure standards of living in the economy. This last point is necessary to reduce discretion and uncertainty about how the mandate of the system evolves over time. One option is to define these parameters as a function of economy-wide average earnings. Thus, when standards of living in the economy increase the mandate of the system is expanded accordingly.

To avoid a level of precautionary savings that is too high, maximum levels of mandatory savings should be set. Individuals who accumulate balances in their unemployment account above this maximum would be allowed to withdraw benefits and/or stop contributing. The limit, for instance, could be a capital that finances 6-12 months of benefits (given the targeted replacement rate). 
Finally, in terms of the covered population, UISAs offer the potential to gradually delink coverage from the labor contract. Initially coverage would focus on formal sector wage earners with open-ended contracts. These workers are already part of the social insurance system and are considered a more stable/predictable group. Yet, the real social benefit of income protection systems comes from covering individuals with limited savings capacity (unskilled self-employed workers and wage earners in small firms including informal ones) who face higher unemployment risks and have less resources to self-insure. As discussed above, UISAs can be extended to these groups because UISAs allow for the separation of insurance and redistributive functions of the system. If the latter is modest and well targeted, it can reduce moral hazard and contain fiscal costs (see also Robalino and Sanchez-Puerta, 2009).

\section{Payment arrangements}

In general, it is preferable that benefit payments take the form of monthly installments and not lump sums. If the focus of the system is on consumption smoothing, in part because of individual myopia, there is no good justification to pay benefits as a lump sum. Doing so can provide incentives to increase turnover or informal work. Moreover, if savings are mismanaged individuals might not have adequate income protection during the entire unemployment spell.

Also, there is little rationale to allow unemployment savings (below the maximum capital) to be used to finance investments or cover other life events. As discussed in the previous section, giving this flexibility provides incentives for higher turnover. Moreover, it reduces the level of precautionary savings necessary to manage adequately unemployment risks. If additional arrangements are needed to promote savings or provide access to credit, specific instruments, not related to the unemployment benefit system, should be considered. 


\section{Credit and the use of pension wealth}

UISA systems can also allow workers to "borrow," although ideally the individual's pension wealth ${ }^{4}$ would serve as collateral. As mentioned, individuals could borrow when the balance in the individual account is not enough to cover the targeted replacement rate, after taking into account the minimum benefit (or unemployment subsidy). To avoid default on the debt and incentives to evade the system, individuals would have the option to repay from the existing pension wealth. The implication is that borrowing could only take place when the pension wealth is above a certain minimum. For example, the Jordanian UISA proposal imposes a borrowing limit equivalent to three times the individual's monthly wage in order to avoid overleveraging of the pension wealth.

The opportunity to "borrow" can preclude increases in often already high social security contributions and, in general, improve individuals' well being by giving them the possibility to tap into long term savings. As pointed out earlier, the key weakness of a pure UISA scheme is the inadequate protection towards those plan members who do not save enough before becoming unemployed. A high contribution rate can accelerate savings, but very likely at the cost of an increased tax wedge. At the same time, reallocating revenues from other branches of the social security is seldom feasible; it would require adjusting benefits levels in systems that tend to be already insolvent.

Even if the allocation of the contribution rate between unemployment and pension benefits is "balanced," allowing individuals to borrow (or simply consume) pension wealth while unemployed is welfare increasing. This is shown formally in Annex 3.

\section{The redistributive component}

The key choices are related to the vesting period, targeting mechanisms, and whether to use ex-ante or ex-post transfers.

\footnotetext{
4 The pension wealth is the present value of the pension benefit cash flow calculated based on pension contributions made up-to-date. In case of a defined contribution (DC) pension scheme, the pension wealth equals to the individual's pension account balance. The calculation is more complicated in the case of a DB system, but it is also possible. Individuals in DB plans, for instance, would receive slightly lower defined benefit (DB) pensions until the UISA debt is fully repaid.
} 
Having in place a minimum vesting period is important to improve incentives to contribute and control costs. This vesting period is not necessary in the case of the contributory part of the benefit (which is self-financed) but, as in the case of UI, it is a must for the redistributive part. The longer the vesting period, the higher the savings that individuals accumulate, the lower the take-up rate and, therefore, the lower the demand for subsidies. At the same time, vesting periods that are too long imply that workers go through long periods without adequate protection. Vesting periods ranging between six months and one year could be considered. The choice will have to be determined, in part, by the duration of the subsidized benefit (see previous subsection). The longer the duration, the longer the vesting period would need to be (for a more rigorous discussion see also Chapter 5 in Robalino et al. [forthcoming]).

It is also important to allocate transfers (subsidies) based on a resource test. Indeed, for a given level and duration of the transfer, a resource test reduces fiscal costs; for a given budget, it allows concentrating resources on those that need them the most. Clearly, resource tests also impose costs. First, they introduce an effective marginal tax rate (EMTR) for individuals close to the eligibility line, who could then reduce labor supply. Also, the system is more expensive to administer. The first problem, however, is less important when the transfer is modest (it affects less people) and, in any case, it can be mitigated by a gradual withdrawal of the transfer, or a claw-back rate (Piggot et al., 2009). As for administration, targeting systems have evolved considerably and their costs plummeted. Even low income countries have successfully adopted these systems to operate the now widely used conditional cash transfers. In developing countries where income is hardly observable but certain components of consumption are, it would be logical to utilize the proxy-means testing targeting systems built for social safety net programs also for the subsidies associated with the UISA system. The challenge is to find the set of observable consumption components (and individual characteristics) that could effectively identify individual and household positions in the income distribution for layers above the poorest that is, those with existing but limited savings capacity. 
Regarding ex-post versus ex-ante transfer there is still no definite answer. In principle, ex-ante interventions can improve incentives for work and reduce the economic cost of the system. The reason being that ex-post transfers (say a minimum benefit paid for two months after the balance in the individual account has run out) impose a tax on individuals who exit unemployment with positive account balances (an EMTR on the transfer). There are thus incentives to prolong the unemployment spell. An alternative is to pay the transfer ex-ante, when the individual is still working. For instance, for each day of contribution to the income protection system the government could offer a match of one day up to a total of one or two months. This design would be more cost effective if it shortens the unemployment spell. The incentive is there because individuals that maintain a short unemployment spell keep the transfer for future consumption (Robalino and Sanchez-Puerta, 2009) - and as mentioned, the Chilean experience provides an empirical confirmation of such incentives. The idea is similar to the reemployment grant used by the Employment Insurance Fund in Korea where individuals who find a job are allowed to receive half of their "remaining" unemployment benefits. Another important feature of ex-ante transfers is that they these would be less dependent from the business cycle.

\section{Financing mechanisms}

In pure UISAs, worker and employer contributions feed the accounts and future benefits are fully funded (i.e., contributions are invested in financial assets). Nevertheless, in practice, the choices are more complicated. First, the UISAs can be pay-as-you-go or notional (NUSAs), which can reduce the level of the contribution rate and fiscal costs. NUSAs do not require a structure that manages the assets of the system and can be implemented even when the financial sector is underdeveloped. Second, important choices need to be made in terms of how to finance the redistributive component (e.g., payroll taxes, general revenues, or a dismissal tax).

NUSAs operate like UISAs but contributions during a given period of time can be used to pay benefits - they are not invested in financial assets. They are the equivalent of the Notional Defined Contribution (NDC) system, a DC design with pay-as-you-go financing, in pensions. Contributions are still registered in individual accounts on a computer as an 
accounting entry. Yet, instead of being used to purchase financial assets, contributions can be used to pay current benefits. One way to think about this financing method is as if the government was borrowing the contribution revenues from the UISA scheme and in exchange, issuing government bonds to the UISA scheme: the government would then use the borrowed revenues to finance transfers to the UISA system. In fact, if the government bonds representing the borrowing are truly issued (the equivalent to the Buchanan bond in pensions), then the expressions "funded" and "pay-as-you-go" become relative and the government’s implicit obligations borne in the scheme become explicit.

One potential advantage of NUSAs is that they can reduce the contribution rate to the system. Assume that all individuals face the same unemployment risks (i.e., the heterogeneity of the unemployment risk structure imposes no systematic redistribution). Individuals could continue to pay a contribution close to the one used in the case of classical unemployment insurance, since the surpluses of some accounts can be used to pay the deficits of others (contributions are not invested in financial assets). Upon retirement a negative balance could be financed through a combination of "excess" pension wealth and an explicit tax (see below). Yet, if the system is well designed, only a minority of individuals would retire at a given point in time. Thus, the sum of the contribution rate and the tax could still be below the total contribution rate of an equivalent funded UISA scheme. The only condition is that the rate of return on the individual accounts takes the growth rate of wages and the liabilities of the system into account (for a more detailed discussion see Robalino and Bodor, 2009).

Even if the contribution rate is set at the same level as in the case of funded UISAs, NUSAs can facilitate the financing of temporary borrowing and the redistributive component. This is simply due to the fact that the social security system and/or the government can use revenues from the contributions to lend unemployment benefits and/or finance unemployment transfers. Clearly, the government in this case would be creating a liability with the NUSA system that would need to be properly accounted for and, at some point, repaid. The same philosophy applies in the case of an NDC system with contributions invested in government bonds (Robalino and Bodor, 2007). 
Regarding the financing of the redistributive component, choices will depend on the coverage of the unemployment benefits system. There are essentially three mechanisms to finance the transfers: (i) payroll taxes and social security contributions, (ii) the general budget, or (iii) ear marks, which could also be considered part of general budget. If coverage is large, it would be more efficient to rely on a combination of general revenues and the proceedings of a dismissal tax. Indeed, a payroll tax would increase the tax wedge (with negative impacts on employment) as well as increase the earnings gap between formal and informal jobs, thus promoting informality. There are, on the other hand, good reasons to use a dismissal tax, which internalizes the social costs of dismissals (Blanchard and Tirole, 2003 and 2004; Baumann and Stahler, 2006). Conversely, if coverage is low and focused predominantly on formal sector workers, using general revenues can be regressive. In this case, financing redistribution within the system (probably also including the dismissal tax) would be the best way to go.

\section{How UISA-Cum-Borrowing Systems Can Serve as a Rapid Response to Economic Crisis}

Vesting periods delay the payment of benefits to the program's first recipients well beyond the introduction of the program, so setting up a new unemployment benefit program can hardly be considered as a part of a rapid response to an economic crisis. Unemployment benefit (UB) programs typically require a minimum contribution period of 612 months so as to limit program abuse. This means that typically the payment of unemployment benefits to the program's first recipients endures a substantial lag following the introduction of a UB scheme: the introduction of a UB scheme, in general, can hardly be considered as a rapid crisis response.

However, a UISA-cum-borrowing scheme backed by an existing pension scheme could start paying benefits within a short period of time, and thus could serve as a rapid response to crisis. In line with the arguments outlined above, for those countries that do not have but would like to introduce an UB program in response to the emerging crisis, a rapid introduction of UISAs backed by the pension wealth is an option. The proposed scheme could work as follows. Upon being laid off, workers enrolled in social security would 
become entitled to borrow, under certain conditions and up to a predetermined threshold, from their USIAs established under the new UB program. Their accumulated pension wealth would act as collateral and perhaps also as a source of funding. By relying on past social security contributions as a qualifying condition, such a scheme could be made operational in a short time frame, and could eventually be transformed to a permanent scheme by mandating regular (worker and employer) contributions. Because such an arrangement would piggyback on the existing administrative capacity of the social security system to deliver unemployment benefits, it could be implemented quickly (for example, in 4-6 months).

Note that the unemployment benefit scheme introduced this way would be sustainable as workers would repay the scheme primarily from future employment income and secondarily from future pensions that is, at a time when the crisis has subsided. Moreover, instead of the government assuming the burden of the stimulus by issuing government debt, and then repaying the debt via future tax revenues, this mechanism allows credit-constrained individuals to do the borrowing themselves at a time when credit is even more scarce than usual (see also Annex 3).

\section{Implementing and Managing UISAs}

UISAs initially evolved in Latin American countries where pension reforms established privately managed pension funds. More developed capital markets, more government oversight, and stronger institutional capacity created the ideal environment for UISAs. Still, in developing countries with publicly run pension schemes, the case can be made for piggybacking on the administrative capacities of the pension (or broader social security) administration.

The Chilean UISA-cum-solidarity fund mechanism is run by a private provider selected through a competitive bidding process. The provision of services associated with the UISA scheme is defined by a contract between the government and the selected provider for a period of 10 years. This contract specifies all the related activities in detail spanning from contribution collection via customer service, to benefit processing, records, and investment management, etc. The provider is selected based on an established record of 
having offered similar services in the area of pensions long before the introduction of the UISA scheme. The government oversight related to the implementation of the contract is carried out by the Pension Supervisory Agency. The Chilean administrative model could be followed by developing countries with developed capital markets and privately run mandatory pension schemes, a rarely existing precondition.

An alternative is to allow the public pension administration handle the administration of UISAs. The main business processes in the administration of UISAs are as follows: (i) contribution collection, (ii) account management, (iii) benefit processing, (iv) investment management, and (v) assistance in job search. Contribution collection for other social insurance components is already in place in countries with contributory pension systems and adding an additional component to the payroll deductions would be easy. Similarly, proper account management is a necessity in any well managed pension system. Indeed, even in Defined Benefit system it is necessary to track the contributions and earnings of plan members. Notional Defined Contribution (NDC) pension schemes also require individual account-based record keeping. ${ }^{5}$ In terms benefit processing there are no major differences either. There are issues that could emerge, however, if there is no institutional capacity and good governance to properly manage and invest the savings accumulated in the individual accounts. When this is the case, however, countries can consider having pay-as-you-go unemployment accounts (NUSAs). As discussed above, these would be the equivalent of NDCs to funded defined-contribution pensions - of financial defined contributions (FDCs) systems.

Regarding job status verification, there is no need to impose a massive burden in terms of monitoring. This is because UISAs severely limit the incentives to abuse the system. What is necessary is to involve (public or private) employment services focusing on jobsearch assistance and retraining in the context of an integrated Labor Market Risks Management (LMRM) system. To design these programs, policymakers can build on the positive experiences of a few Latin American countries (see Robalino and Sanchez-Puerta for a review). Hence, instead of trying to monitor employment and job search, the emphasis

\footnotetext{
${ }^{5}$ DB pension systems with strong correspondence between contributions and benefits can be mathematically identical to NDC schemes.
} 
would be on monitoring enrolment in job-search assistance and/or training programs (as appropriate) which is easy to enforce.

\section{Concluding Remarks}

The paper focused on a nontraditional - and as claimed by the authors, so far underutilized - mechanism for providing unemployment benefits, UISAs. It showed that certain designs of UISAs - especially UISAs-cum-borrowing with the pension wealth as collateral - have the potential of providing adequate income protection and, at the same time, avoiding the moral hazard present in traditional, OECD-style unemployment insurance (UI) programs. Allowing the unemployed to draw resources from their UISAs when the balance on these accounts is negative considerably enhances welfare properties of the scheme (for example, it allows the receipt of benefits by workers with insufficient balances on their UISAs, such as young workers), and the backing of the scheme with the pension wealth increases flexibility in the management of savings and therefore allows the system to achieve its consumption smoothing function more efficiently. The quantitative analysis conducted in the context of the paper showed that reducing restrictions in the use of pension wealth is particularly important in the case of risk averse individuals and when the unemployment rate is not too "high." At the same time, policymakers need to be careful in setting the share of pension wealth that can be used in the case of unemployment. In general, there should be a minimum level of pension wealth that is maintained to guarantee a minimum level of income during old age. Full access to pension wealth is thus not an efficient policy. The share of pension wealth that can be used for unemployment would depend on the targeted minimum level of consumption that system offers to workers.

The paper thus argued that UISAs are a particularly appropriate tool for developing countries. A standard, OECD-type UI program requires monitoring of the job search and labor market status of benefit recipients and therefore is not a good fit for developing countries that have vast informal sectors and much weaker administrative capacity than developed countries; moreover, such programs exclude informal sector workers. Instead of relying on monitoring of benefit recipients, UISAs internalize the costs of unemployment benefits and thus strengthen financial incentives (and this "self-policing," as shown by new 
empirical evidence from Chile, indeed works) - the feature particularly important for developing countries. Furthermore, UISAs offer the possibility to extend coverage to informal sector workers.

Not only are UISAs an attractive option for non-crisis times, but the version that relies on borrowing against pension wealth also enables a rapid introduction of the program and can be, therefore, used to boost the incomes of unemployed workers affected by the current crisis. Indeed, by relying on past social security contributions as a qualifying condition and by utilizing existing social security capacity to deliver the benefits, such a scheme could be made operational in a relatively short time. 


\section{References}

Acevendo, G., P. Eskenazi and C. Pagés. 2006. Unemployment Insurance in Chile: A New Model of Income Support for Unemployed Workers. Social Protection Discussion Paper No. 0612. Washington DC: World Bank.

Barr, N. 2001. The Welfare State as Piggy Bank: Information, Uncertainty and the Role of the State. Oxford: Oxford University Press.

Baumann, F. and N. Stähler. 2006. Financing Unemployment Benefits: Dismissal versus Employment Taxes. Labour 20 (3): 433-451.

Bernheim, D. and A. Rangel. "Behavioral Public Economics: Welfare and Policy Analysis with Nonstandard Decision-Makers." In Behavioral Economist and its Applications, edited by Diamond, P. and H. Vartiainen. Princeton: Princeton University Press, 2007.

Blanchard, O. and J. Tirole. 2003. Contours of Employment Protection Reform. MIT Department of Economics Working Paper No. 03-35.

Blanchard, O. and J. Tirole. 2004. The Joint Design of Unemployment Insurance and Employment Protection: A First Pass. MIT Department of Economics Working Paper No. 04-15.

Bodor, A. and H. Rahahleh. 2009. The Protection Adequacy of the Proposed Jordanian Unemployment Insurance Savings Accounts Mechanism with Possible Leveraging of the Pension Wealth. Forthcoming. Washington DC: World Bank.

Gonzaga, G. 2003. Labor Turnover and Labor Legislation. Economía, Journal of the LACEA, 4 (1): 166-222.

Dorfman, M. and D. Robalino. 2009. Managing PAYG Reserves and the Role of GDP Indexed Bonds. Forthcoming. Pension Primer. Washington DC: World Bank.

Eslava, M., J. Haltiwanger, A. Kugler and M. Kugler. 2009. Factor Adjustments after Deregulation: Panel Evidence from Colombian Plants. Review of Economic and Statistics. Forthcoming.

Feldstein, M. and D. Altman. 1998. Unemployment Insurance Savings Accounts. NBER Working Paper No. 6860.

Holmlund, B. 1998. Unemployment Insurance in Theory and Practice. Scandinavian Journal of Economics 100 (1): 113-152.

Kugler, A. "The Effect of Job Security Regulations on Labor Market Flexibility: Evidence from the Colombian Labor Market Reform.” In Law and Employment: Lessons from 
Latin America and the Caribbean, edited by Heckman, J. and C. Pagés. Chicago: The University of Chicago Press, 2004.

Kugler, A. 2005. Wage-Shifting Effects of Severance Payments Savings Accounts in Colombia. Journal of Public Economics 89 (2-3): 487-500.

Orszag, J., P. Orszag, D. Snower and J. Stiglitz. "The Impact of Individual Accounts: Piecemeal versus Comprehensive Approaches.” Paper presented at the Annual Bank Conference on Development Economics, World Bank, Washington, DC, April 29, 1999.

Orszag, J. and D. Snower. 2002. From Unemployment Benefits to Unemployment Accounts. IZA Discussion Paper No. 532. Bonn: Institute for the Study of Labor.

Piggot J., D. Robalino and S. Jimenez-Martin. "Incentive Effects of Retirement Income Transfers." In Closing the Coverage Gap: The Role of Social Pensions and Other Retirement Income Transfers, edited by Robalino D., R. Holzmann, and O. Takayama. Washington DC: World Bank, 2009.

Robalino, D. and A. Bodor. 2007. On the Financial Sustainability of Earnings-Related Pension Schemes with Pay-As-You-Go Financing and the Role of GovernmentIndexed Bonds. Journal of Pension Economics and Finance 8 (2): 189-223.

Robalino, D. and A. Bodor. 2009. Notional Unemployment Insurance Savings Accounts. Forthcoming. Pension Primer. Washington. DC.

Robalino, D., A. Mason, H. Ribe and I. Walker. 2009. From Right to Reality: How can Latin America and the Caribbean Extend the Coverage of Social Protection to All Citizens? Adapting programs to informality and labor mobility, making subsidies fair and transparent, and strengthening labor services and safety nets". Washington DC: World Bank.

Robalino, D., E. Zylberstajn, H. Zylberstajn and L.E. Afonso. 2009. An Ex-Ante Evaluation of the Impact of Social Insurance Policies on Labor Supply in Brazil: The Case for Explicit over Implicit Redistribution. Social Protection Discussion Paper. Washington DC: World Bank.

Robalino, D. and L. Sanchez-Puerta. 2008. Managing Labor Market Risks and Creating Better Jobs: Alternative Designs for Income Protection and Active Labor Market Policies. Mimeo. Washington DC: World Bank.

SAFP. 2007. Five Years of Unemployment Insurance in Chile: Diagnosis and Challenges for Improvement. Report of the Superintendencia de AFP. Santiago de Chile.

Stiglitz, J. and J. Yun. 2008. Public Provision of Self-Insurance Against Unemployment. Mimeo. New York: Columbia University. 
Stiglitz, J. and J. Yun. 2005. Integration of Unemployment Insurance with Retirement Insurance. Journal of Public Economics 89: 2037-2067.

van Ours, J. and M. Vodopivec. 2006. How Shortening the Potential Duration of Unemployment Benefits Affects the Duration of Unemployment: Evidence from a Natural Experiment. Journal of Labor Economics 24 (2): 351:378.

van Ours, J., G. Reyes Hartley, and M. Vodopivec. 2009. "Incentive Effects of Unemployment Insurance Savings Accounts: Evidence from Chile,” World Bank Social Protection Discussion Paper. Forthcoming. Washington DC: World Bank.

Vodopivec, M. 2004. Income Support for the Unemployed: Issues and Options. Regional and Sectoral Studies Series. Washington DC: World Bank.

Vodopivec, M. 2006. Choosing a System of Unemployment Income Support: Guidelines for Developing and Transition Countries. The World Bank Research Observer 21 (1): 4989.

Vodopivec, M. 2008. How Viable Are Unemployment Insurance Savings Accounts: Simulation Results for Slovenia. IZA Discussion Paper No. 3438, April 2008. Bonn: Institute for the Study of Labor (forthcoming in Comparative Economic Studies)

Vodopivec, M. 2009. Introducing Unemployment Insurance to Developing Countries. Social Protection Discussion Paper No. 0907. Washington DC: World Bank.

Vodopivec, M., A. Wörgötter and D. Raju. 2005. Unemployment Benefit Systems in Central and Eastern Europe: A Review of the 1990s. Comparative Economic Studies 47 (4): 615-651. 


\section{Annex 1: Stylized Features of UISAs from Selected Latin American Countries}

Table 1 summarizes the key parametric features of UISAs from selected Latin American countries. Note that the unemployment benefit is paid as a lump sum in Argentina, Colombia, Ecuador, and Peru. The maximum unemployment duration parameter does not apply in these cases.

Also note that the contribution rates in these examples are high compared to the contribution rates that apply in traditional unemployment insurance (UI) systems with risk pooling. (Chile is a remarkable exception!) The reason beyond the ones already discussed in this paper for these high contribution rates is that some of these USIA systems do not only target income support for a reasonably short frictional unemployment spell, but they serve as replacements for generous pre-existing severance pay schemes. The high contribution rates are necessary to match the generosity of these severance pay schemes. The primary example is Columbia where the UISA scheme is really a prefunding mechanism replacing the severance pay scheme, which offered one monthly wage severance pay for each year of service. This level of generosity is roughly equivalent to a prefunding mechanism with an 8 percent contribution rate in cases under which the severance pay eligibility is not conditional on the cause of separation (see Kugler [2005] for more details).

The existing UISA scheme that demonstrates the ability of UISAs to provide adequate income protection with a reasonably low contribution rate is the Chilean scheme (see SAFP [2007] and Acevedo et al. [2006] for details).

Table 1: Income Replacement Rates, Contribution Rates and Maximum Benefit Duration of UISAs in Selected Latin American Countries

\begin{tabular}{|c|c|c|c|}
\hline & $\begin{array}{c}\text { Replacement rate (\% of the } \\
\text { individual's pre- } \\
\text { unemployment wage) }\end{array}$ & $\begin{array}{c}\text { Contribution rate (employer + } \\
\text { work obligation assessed on the } \\
\text { individual's wage) }\end{array}$ & $\begin{array}{l}\text { Max Benefit } \\
\text { Duration } \\
\text { (month) }\end{array}$ \\
\hline $\begin{array}{c}\text { Argentina } \\
\text { (construction } \\
\text { sector only) }\end{array}$ & lump sum & $12 \%$ (8\% after first year) $+0 \%$ & N/A \\
\hline Brazil & $\begin{array}{c}\text { lunp sum }+40 \% \text { if not } \\
\text { dismissed for "just cause" }\end{array}$ & $8 \%+0 \%$ & 6 \\
\hline Chile & $30-50 \%$ & $2.4 \%+0.6 \%$ & 5 \\
\hline Colimbia & lump sum & $9.3 \%+0 \%$ & N/A \\
\hline Ecuador & lump sum & $8 \%+0 \%$ & N/A \\
\hline Peru & lump sum & $8 \%+0 \%$ & N/A \\
\hline Uruguay & $50 \%$ & $\begin{array}{l}\text { hidden in total social insurance } \\
\text { CR: } 15 \%+12.2 \%\end{array}$ & 6 \\
\hline
\end{tabular}

Source: Vodopivec [2006]. 


\section{Annex 2: The Chilean UISAs-Cum-Solidarity Fund Scheme}

The Chilean UISA-cum-solidarity fund scheme was introduced in 2002. The main idea of the Chilean system is to take advantage of the desirable incentive effects of pure UISAs as the overriding mechanism behind the scheme and to augment it with some degree of risk-pooling to improve the benefit adequacy for those plan members who saved little before they become unemployed.

Employees and employers both contribute to the individual accounts at contribution rates 0.6 percent and 1.6 percent respectively. When workers become unemployed (regardless of the reason for separation) they can withdraw the funds accumulated on their individual accounts. If the accumulation on the individual account is larger than the financing need for five monthly benefit payments starting at 50 percent, then gradually decreasing to 30 percent of the covered pre-unemployment wage, then only the individual account finances the benefits. Alternatively, the solidarity fund augments the saving on the individual account to finance the five monthly benefit payments as described above. The solidarity fund is financed by a contribution from employers at 0.8 percent of all the covered wages of their employees. Thus, the overall contribution rate paid by employers is 2.4 percent. The government also contributes to the solidarity fund by a fixed annual payment. The total contribution rate financing the Chilean UISA mechanism excluding the government contribution is 3 percent, a low rate compared to other UISA schemes in Latin America. See Figure 2 for an illustration of the Chilean UISA scheme.

Figure 2: The Chilean USIA System

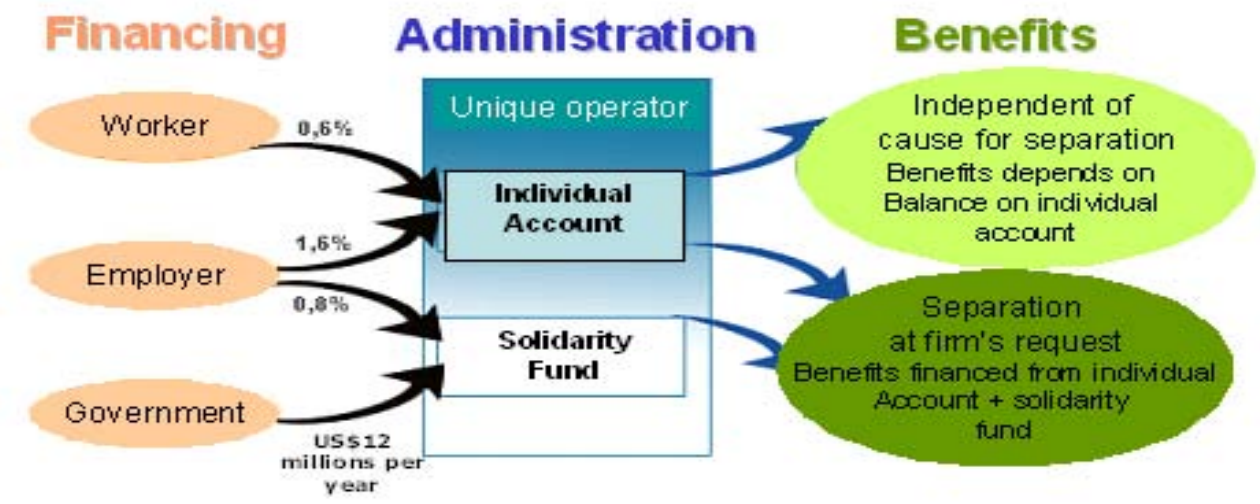

Source: Presentation by Eduardo Fajnzylber at the "Optimal Unemployment Insurance Design: RiskPooling and/or Mandatory Savings” workshop organized by the World Bank's Human Development Department, Middle East and North Africa Region on May 22, 2008.

There is an important distinction between the eligibility for benefits solely financed from the individual accounts and the ones co-financed by the solidarity fund. While benefits solely financed by the individual account can be accessed regardless of the voluntary or involuntary nature of the separation, benefit payments involving the solidarity fund require that the worker be involuntarily laid off. 
A review of the first five years of the Chilean UISA system suggested that the generosity of the system towards fixed-term employees could be improved, that is why limited access to the solidarity fund was also granted to workers with fixed-term employment contracts in 2008. Initially, the access to the solidarity fund was restricted to workers with open-ended employment contracts.

\section{Annex 3: Formalizing the Welfare Effects of Restrictions in the Access to Pension Wealth}

The paper so far has discussed, intuitively, that allowing individuals to "borrow" against their pension wealth while unemployed can be welfare increasing. Indeed, credit constrained individuals would gain by having the flexibility to access an asset previously inaccessible before retirement and any concerns regarding the depletion of this pension wealth could be dealt with by imposing restrictions on the level of borrowing. This section first formalizes this argument using a simple three period model of optimal savings. It then uses simulations of real career histories to estimate the magnitude of the welfare losses (gains) induced by restricting access to the pension wealth to a varying degree.

\section{The three period model of optimal savings for pensions and unemployment}

We work with individuals that have time inconsistent preferences (which justify mandatory savings) and live three periods. During the first period all consumers work, but they can be unemployed during the second period with a probability $\mathrm{u}$. In the last period all consumers are retired. The representative consumer chooses the savings rate in period 1 and 2 to solve the following problem:

$$
\begin{aligned}
\max : & U\left(c_{1}\right)+\beta\left[\rho U\left(c_{2}\right)+\rho^{2} U\left(c_{3}\right)\right], \\
& \text { s.t. } c_{3}=\left[\left(y_{1}-c_{1}\right) R+y_{2}-c_{2}\right] R
\end{aligned}
$$

Where c represents consumption, y income, $\rho$ captures consumers time-preferences, $R=(1+r)$ where $r$ is the interest rate, and $\beta$ is a parameter capturing the degree of "myopia." In the special case of $\beta=1$ the individual exhibits time consistent preferences, i.e. the rate of time preference between any two consecutive periods is identical, but if $\beta$ is below or above one, then individuals have a higher or lower discount rate between the current period and the next period compared to any other consecutive time periods. Such time inconsistent preferences lead to under-saving or over-saving. ${ }^{6}$

To gain insights we assume a standard constant relative risk aversion utility function

$U(c)=\frac{c^{1-\lambda}}{1-\lambda}$ where $\lambda$ is the coefficient or risk aversion, and solve the problem recursively.

\footnotetext{
${ }^{6}$ See Bernheim and Rangel [2007] for this type of “naïve” formulation of myopia.
} 
Hence, in period 2 consumers observe their savings $k_{2}=\left(y_{1}-c_{1}\right) R$ and their income $y_{2}$ and choose $c_{2}$ to solve for the first order condition:

$$
\frac{\partial U\left(c_{2}\right)}{\partial c_{2}}=-\beta \rho \frac{\partial U\left(c_{3}\right)}{\partial c_{2}}
$$

with $c_{3}=\left(k_{2}+y_{2}-c_{2}\right) R$

This gives:

$$
c_{2}^{-\lambda}=\beta \rho R\left[\left(k_{2}+y_{2}-c_{2}\right) R\right]^{-\lambda},
$$

or after simplification:

$$
c_{2}=\frac{\left(k_{2}+y_{2}\right)}{\psi_{2}}
$$

with $\psi_{2}=\frac{\left(1+(\beta \rho R)^{\frac{1}{-\lambda} R}\right)}{(\beta \rho R)^{\frac{1}{-\lambda}} R}>1$.

Similarly, for period 1, the first order condition is:

$$
c_{1}^{-\lambda}=\beta \rho \frac{R}{\psi_{2}}\left[\frac{\left(\left(y_{1}-c_{1}\right) R+y_{2}\right)}{\psi_{2}}\right]^{-\lambda},
$$

So the solution for the first period consumption is given by:

$$
c_{1}=\frac{\left(y_{1} R+y_{2}\right)}{\psi_{2} \psi_{1}}
$$

with $\psi_{1}=\frac{\left(1+\left(\beta \rho \frac{R}{\psi_{2}}\right)^{\frac{1}{-\lambda}} \frac{R}{\psi_{2}}\right)}{\left(\beta \rho \frac{R}{\psi_{2}}\right)^{\frac{1}{-\lambda}}}$ 
We are then interested in characterizing optimal savings for pensions and optimal savings for unemployment. Optimal savings for pensions can be simply derived by assuming that there is no unemployment. Thus, normalizing income to 1, we have:

$$
k_{p}=1-\frac{(R+1)}{\psi_{2} \psi_{1}}
$$

Deriving optimal savings with uncertainty regarding employment status in period 2 is more cumbersome. The first order condition is given by:

$$
c_{1}^{-\lambda}=\beta \rho \frac{R}{\psi_{2}}\left\{(1-u)\left[\frac{\left(\left(y_{1}-c_{1}\right) R+y_{2}\right)}{\psi_{2}}\right]^{-\lambda}+u\left[\frac{\left.\left(y_{1}-c_{1}\right) R\right)}{\psi_{2}}\right]^{-\lambda}\right\},
$$

where $\mathrm{u}$ is the probability of being unemployed in period 2. There is no analytical solution to (8), but we know that the optimal level of consumption with $0<\mathrm{u}<1$ has to fall "in between" the level of consumption with $\mathrm{u}=0$ and $\mathrm{u}=1$. Hence, one can write the optimal level of consumption for $0<\mathrm{u}<1$ as a weighted average of $\mathrm{c}^{*}(\mathrm{u}=1)$ and $\mathrm{c}^{*}(\mathrm{u}=0)$. The weight is zero when $\mathrm{u}=0$ and 1 when $\mathrm{u}=1$. In between, the weight has to increase monotonically with $\mathrm{u}$. Indeed, other things being equal, as the probability of unemployment increases, the weight has to increase to reduce consumption and increase savings (see Figure 3)

\section{Figure 3: Characterizing Optimal Consumption under Uncertainty in Employment in Period 2}

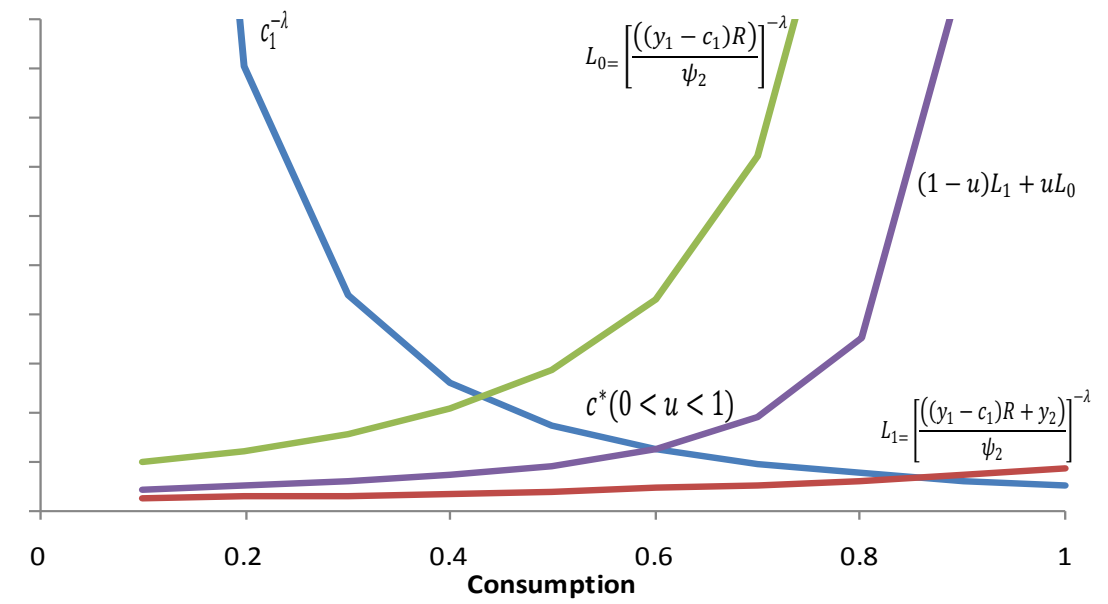

Note: The figure is based on equation (8). The parameter u represents the probability of unemployment in period 2.

Source: Authors' calculations. 
Thus, the level of saving necessary to cover pensions plus the risk of unemployment can be computed as a weighted average of the levels of savings without unemployment and the savings with unemployment (i.e., when $\mathrm{y}=0$ ). We can write:

$$
k=1-\left[(1-\mu(.)) \frac{(R+1)}{\psi_{2} \psi_{1}}+\mu(.) \frac{(R)}{\psi_{2} \psi_{1}}\right],
$$

where $0 \leq \mu() \leq$.1 is an increasing function of the probability of unemployment at time $\mathrm{t}=2$. After simplifying we obtain:

$$
k=1-\frac{(R+1)}{\psi_{2} \psi_{1}}+\frac{\mu(.)}{\psi_{2} \psi_{1}},
$$

Thus, the amount of savings to cover for the risk of unemployment is simply the difference between the savings amounts given by (7) and (9):

$$
k_{u}=\frac{\mu(.)}{\psi_{2} \psi_{1}},
$$

The policy question we are interested in is whether in period 2, in the "bad" state (unemployed), the optimal level of consumption (with unrestricted access to capital) is above the unemployment savings. In this case, if there is a restriction on the use of pension wealth, the optimal cannot be achieved and there is a welfare loss.

By replacing $\mathrm{k}$ in (4) and setting $\mathrm{y}_{2}=0$, we obtain the optimal level of consumption if unemployed:

$$
c_{2}^{*}=\frac{k}{\psi_{2}}=\frac{1-\frac{(R+1)}{\psi_{2} \psi_{1}}+\frac{\mu(\cdot)}{\psi_{2} \psi_{1}}}{\psi_{2}},
$$

The constraint on the use of pension wealth will be welfare decreasing as long as the savings to finance unemployment benefits (equation 11) are not sufficient to cover the optimal level of consumption. Formally, the condition for having a welfare loss if pension wealth cannot be used is:

$$
\frac{1-\frac{(R+1)}{\psi_{2} \psi_{1}}+\frac{\mu(.)}{\psi_{2} \psi_{1}}}{\psi_{2}}-\frac{\mu(.)}{\psi_{2} \psi_{1}}>0,
$$

or after simplifying:

$$
\mu(.)<\frac{\psi_{2} \psi_{1}-(R+1)}{\psi_{2}-1},
$$


This condition does not always hold. In particular, it does not hold when $\psi_{2} \psi_{1}<(R+1)$ since in that case the right hand side of the inequality is negative (since $\psi_{2}>1$ ). Hence, given $\mathrm{R}$, for certain combinations of the level of risk aversion and time preferences, restricting the use of pension wealth does not decrease welfare. In particular, it can be shown that $\psi_{2} \psi_{1}$ increases when the level of risk aversion increases and/or when the rate at which individuals discount future consumption decreases. (see Figure 4).

A first result therefore is that, for sufficiently risk taker individuals with high discount rates, condition (14) will not hold. This means that risk taker individuals who heavily discount the future will not be affected by restrictions on the use of pension wealth.

On the other hand, for risk averse individuals with low discount rates (the most likely case) ${ }^{7}$ restrictions on the use of pension wealth can reduce welfare. Whether this happens will depend on the probability of unemployment.

Hence, the second result is that for $\psi_{2} \psi_{1}>(R+1)$, there exists an unemployment probability such that condition (14) holds. The lower the unemployment rate, the more likely that inequality (14) will be verified and that restrictions in the use of pension wealth will be welfare decreasing. Conversely, the higher the unemployment rate the less likely that restrictions on the use of pension wealth will matter.

The intuition behind this result is that, the higher the unemployment rate, the more savings will be accumulated by risk averse individuals to cover unemployment benefits, thus increasing the share of these savings in total savings. Then, these savings alone can be sufficient to finance the optimal level of consumption when unemployed.

\footnotetext{
${ }^{7}$ See Jimenez-Martin and Sanchez-Martin [2007] and Robalino et al., [2009].
} 


\section{Figure 4: Conditions under which Restrictions on the Use of Pension Wealth are Welfare Decreasing}

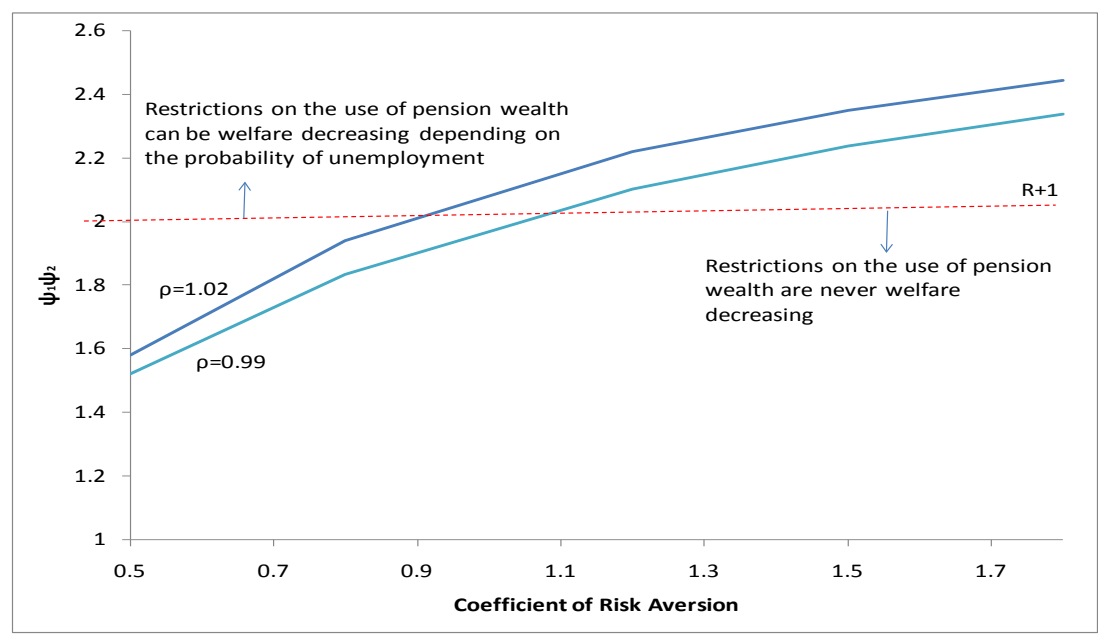

Source: Authors' calculations.

To illustrate these points, we have computed optimal levels of consumption in periods 1,2 and 3 for $\lambda=1.8, \rho=0.99, r=1.04$ and $\beta$ ranging between 1 and 0.666 . The results are summarized in Figure 5. All the lines give the optimal level of consumption as a function of $1 / \beta$ (the level of myopia) and two values of the unemployment rate ( 0 and 1$)$. In the first panel, which corresponds to period 1, the line on the top refers to the case without unemployment. We see that as myopia increases, consumption increases (individuals overconsume). The point where $\beta=1$ gives the "socially optimal" level of consumption $c^{*}$ and the distance between 1 and $c^{*}$ gives the socially optimal level of savings. The line at the bottom does the same for the case where individuals do not work in period $2\left(\mathrm{y}_{2}=0\right)$. Clearly, optimal savings in period 1 in this case are higher, as individuals put aside extra savings to deal with unemployment in period 2. The line in "the middle" gives optimal consumption levels assuming an unemployment probability of $5 \%$. The distance between $\mathrm{Cu}^{*}$ and $\mathrm{C}^{*}$ gives the additional savings that are needed to deal with the risk of unemployment. The story is that, at least in principle, depending on the level of myopia (i.e., the value of the parameter $\beta$ ) governments impose forced savings to ensure that the socially optimal level of savings reaches 1-Cu*. But forced savings usually separate the savings going to the "pensions account" from those going to the "unemployment account." In our example, around 5 percent of total savings would be in the unemployment account and the rest in the pensions account.

The right-panel of Figure 5 shows optimal consumption in periods 2 and 3 (when retired). For period 2 there are two cases: the case where the individual is employed and the case where the individual is unemployed. When employed, restrictions on pension wealth are not an issue. When unemployed, however, these restrictions matter. In the figure, the dotted line 
on top indicates the total level of savings (including forced savings). The dotted line at the bottom represents only the unemployment savings. We see that in all cases these savings are not enough to cover the optimal level of consumption while unemployed. Removing that restriction can therefore be welfare improving.

Figure 5: Optimal Consumption, Optimal Savings and Restrictions on Pension Wealth
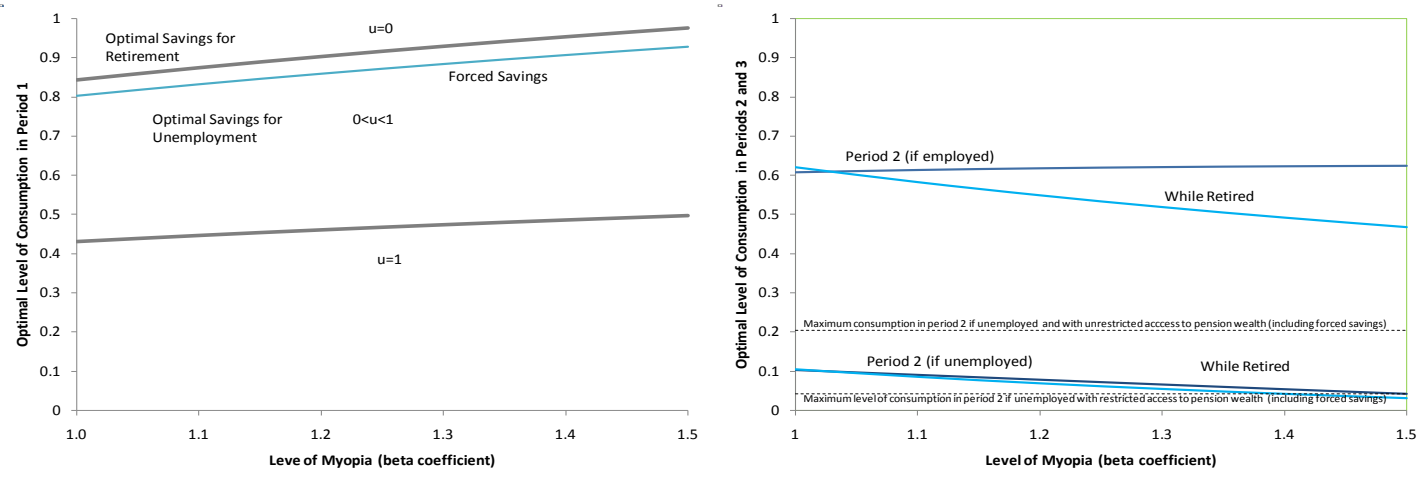

Note: In the figures $\lambda=1.8, \rho=1 /(1+0.01), \mathrm{r}=1.04, \mathrm{u}=0.05$, and $\mathrm{y}$ is set equal to one when employed. Source: Authors.'

\section{Simulating career paths and the welfare impact of restrictions on the use of pension wealth}

In reality, determining what is the optimal level of saving for various risks is very difficult - particularly given that individuals have heterogeneous preferences. In practice, the mandates of the various social insurance programs across countries are determined by the political process. The necessary contribution rates (forced savings) are set accordingly. The more relevant question in this case is how policymakers should set (i) the replacement rate for unemployment benefits, and (ii) the share of pension wealth that can be used in the case of unemployment; given (i) the contribution rate and its allocation between pensions and the unemployment account, and (ii) transitions in and out of unemployment.

To address these questions we set up a simple model where representative individuals can be followed, month by month, starting at the time they enter the labor market, through retirement, until death. While active, individuals can transit between employment and unemployment according to a Markov process given by a matrix $M_{i j}$, which gives the transition probabilities between states $\mathrm{i}$ and $\mathrm{j}$. Both $\mathrm{i}$ and $\mathrm{j}$ can take on the values 1 (if employed) and 0 (if unemployed). The time $t^{*}$ of retirement, expressed in number of months, is defined exogenously. While employed at time t individuals earn a salary given by $w(t)=w(0)(1+g)^{t}$ where $g$ is the monthly growth rate of wages. If unemployed, individuals receive an unemployment benefit given by $B(t)=\min \left(\alpha \cdot w(t), k_{u}+\right.$ 
$\left.\eta\left(k-k_{u}\right)\right)$ where $\alpha$ is the replacement rate for unemployment benefits and $\eta$ is the share of pension wealth that can be used to finance unemployment benefits. When retired, on the other hand, individuals receive a pension $p(t>t *)=k(t *) / a(t *)$ where $\mathrm{a}\left(\mathrm{t}^{*}\right)$ is the annuity factor at the age of the individual at time $t^{*}$.

It is assumed that individuals consume all their net salaries (i.e., salaries after paying social security contributions) and unemployment and pension benefits. Hence, all savings are related to the mandatory contributions to the social security system. In this case, the dynamics of total and unemployment savings before retirement are given by:

$$
\begin{gathered}
k(t+1)=(k(t)+\tau \cdot w(t)-B(t))(1+r) \\
k_{u}(t+1)=\max \left(0,\left(k_{u}(t)+\tau_{u} \cdot w(t)-B(t)\right)(1+r)\right)
\end{gathered}
$$

where $r$ is the interest rate on savings and $\tau$ and $\tau_{\mathrm{u}}$ are respectively the total contribution rate to the social security and the contribution rate that finances unemployment benefits. We notice that when individuals are allowed to use part of the pension wealth then $\mathrm{B}(\mathrm{t})$ can be higher than $\mathrm{k}_{\mathrm{u}}$ - thus the restriction is that $\mathrm{k}_{\mathrm{u}}>0$.

We use the model to simulate the welfare impact of alternative combinations of $\alpha$ $(0.3,0.4, \ldots, 0.7)$ and $\eta(0,0.1, \ldots, 1)$ given $M_{i j}$. We use three transition probabilities between employment and unemployment: $0.01,0.02$, and 0.05 . As a reference, estimates of these probabilities for formal sector workers in Argentina, Brazil and Mexico are: 0.0095, 0.0111, and 0.0058 respectively (see Robalino and Zylberstajn, [2009]). To put things in perspective, a 0.01 monthly probability of unemployment implies that roughly 10 percent of workers become unemployed within a year, while a 0.05 monthly probability of unemployment implies that half of workers become unemployed during the year. Regarding the transition out of unemployment we use a constant 0.25 probability. This is more or less equivalent to an average unemployment duration of 3 months. In addition, we fix the real growth rate of wages $(g=0.03 / 12)$, the real interest rate $(r=0.04 / 12)$, and the contribution rates $(\tau=0.15$ and $\left.\tau_{\mathrm{u}}=0.08\right)$. Welfare is measured with the same utility function used in the previous section setting $\lambda=1.5$ (i.e., we focus on risk averse individuals) and $\rho=1 /(1+r)$.

The results of the simulation are summarized in Figure 6. In each panel, the different lines are associated with a given replacement rate for unemployment benefits. The lines give the average (across 1,000 realizations of Monte Carlo simulations) of the per capita present value of utility as a function of the share of pension wealth that can be accessed in the case of unemployment $(\eta)$. 
The main insights from the analysis can be summarized as follows:

- In all cases, restricting access to pension wealth is welfare decreasing and losses can be considerable. In essence, if unemployment savings are zero and individuals become unemployed, consumption drops to zero. This has a dramatic negative effect on welfare, given the assumption of a decreasing marginal utility to consumption (i.e., when consumption is very low, utility is "very negative.”)

- At the same time, allowing myopic individuals to use 100 percent of their pension wealth can also be a bad policy. What happens in the model in this case is that when individuals become unemployed with unemployment savings equal to zero, they can deplete pension wealth more rapidly and eventually drive it down to zero -- which again generates a level of consumption equal to zero. For $0<\eta<1$, on the other hand, pension wealth (and therefore consumption) never becomes zero. Clearly, as discussed below, this assumes that there is no minimum level of consumption, which in reality is not the case.

- In general, welfare starts to decrease rapidly after $\eta$ has surpassed a given threshold in our illustrations between 0.10 and 0.4 . This is because when the share of pension wealth that is used is low, it is more likely that it will be "spread over the unemployment period,” instead of reaching a level where consumption approaches zero - and that has an important negative effect on welfare. It is important to note, however, that if a restriction existed where consumption cannot fall below a given minimum (say close to the poverty line) then the optimal $\eta$ would increase - if not, the level utility would also become "very negative." We thus postulate that, given a replacement rate (and the other model parameters), there is an optimal $\eta$ that depends on the minimum level of consumption. It is the minimum $\eta$ that allows individuals to keep consumption levels above this minimum most of the time. 
Figure 6: Welfare Impact of Alternative Restrictions on the Use of Pension Wealth

Transition probability into unemployment $=\mathbf{0 . 0 1}$
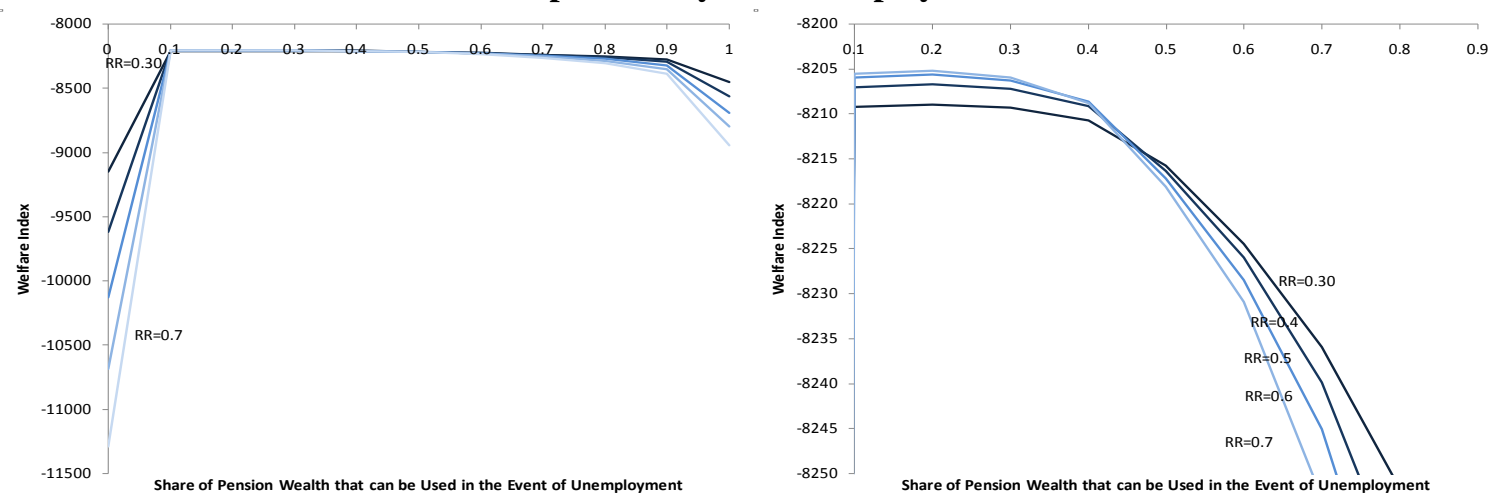

Transition probability into unemployment $=\mathbf{0 . 0 2}$
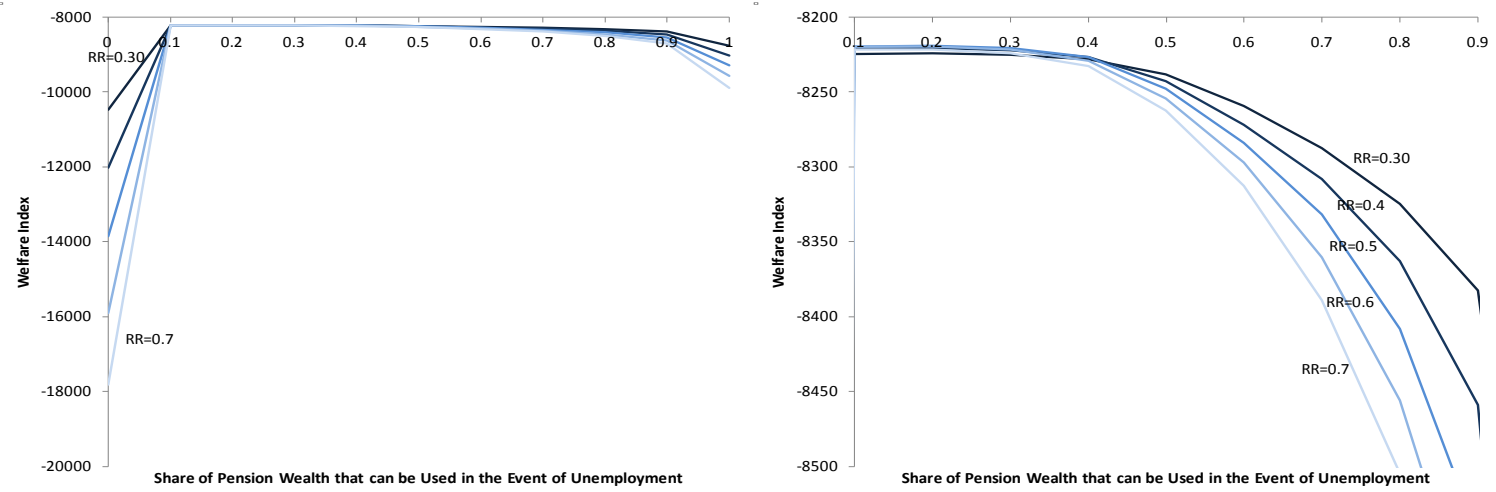

Transition probability into unemployment $=\mathbf{0 . 0 5}$
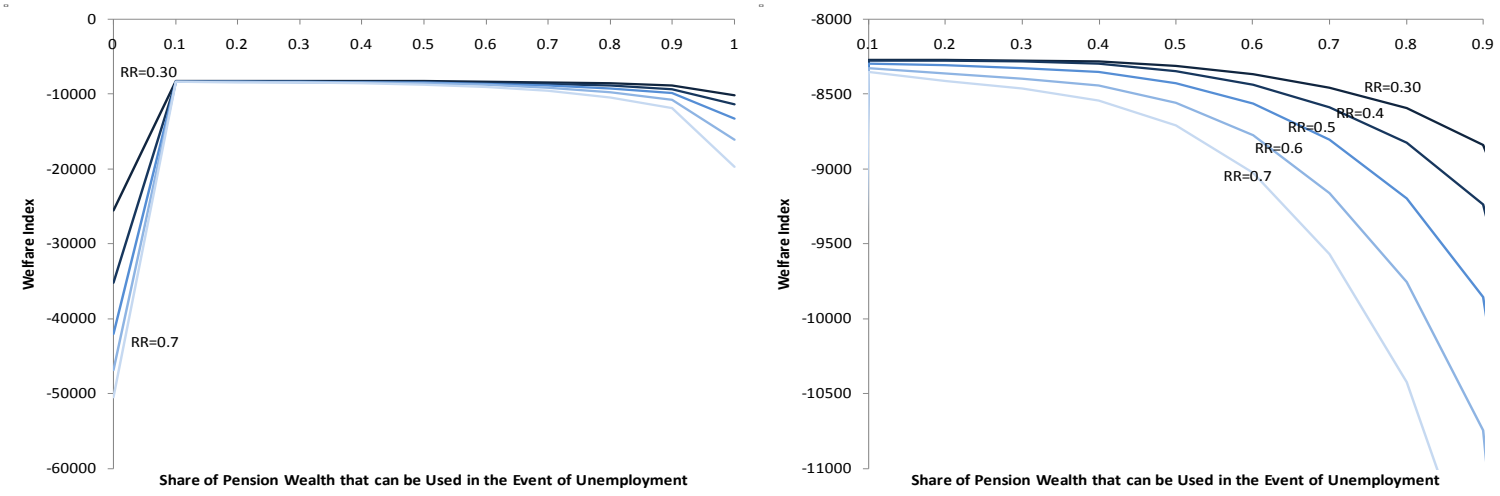

Note: Right panels provide a zoom of the left panels for $0<\eta<1$.

Source: Authors' calculations

- Similarly, we observe that the higher the replacement rate the lower the level of welfare and the more negative the slope of the lines (i.e., the more rapidly utility declines as $\eta$ increases). Again, this is because, given $\eta$, the higher the replacement the more rapidly pension wealth can be depleted. In the current example, 0.3 is the replacement rate that keeps consumption above zero most of the time. But, if there 
was a level of consumption below which the utility became "very negative," the minimum replacement rate would have to increase.

- Finally we see that the effects of $\alpha$ and $\eta$ on welfare are less important when transition probabilities into unemployment fall. Or, given the duration of unemployment, this is equivalent to a decrease in the unemployment rate. This is simply because individuals would spend less time unemployed and therefore would be less likely to deplete pension wealth. The obvious implication is that policymakers need to be more careful in choosing $\alpha$ and $\eta$ when unemployment rates are high.

In summary, the results suggests that both restricting access to pension wealth or allowing individuals to access pension wealth without restrictions are bad policies. Choices about the targeted replacement rate and the share of pension wealth that can be accessed in the event of unemployment should be set as low as possible to ensure that individuals preserve a given minimum level of consumption most of the time. 